\title{
PERSISTENCE AND ACADEMIC ACHIEVEMENT IN FOREIGN LANGUAGE IN NATURAL SCIENCES STUDENTS
}

\author{
Alexandr I. Krupnov, Yulia V. Kozhukhova, Alexandra A. Vorobyeva \\ Peoples' Friendship University of Russia (RUDN University) \\ Miklukho-Maklaya str., 6, Moscow, Russia, 117198
}

\begin{abstract}
The article discusses the results of empirical study of the association between variables of persistence and academic achievement in foreign languages. The sample includes students of the Faculty of Physics, Mathematics and Natural Science at the RUDN University $(n=115)$, divided into 5 subsamples, two of which are featured in the present study (the most and the least successful students subsamples). Persistence as a personality trait is studied within A.I. Krupnov's system-functional approach. A.I. Krupnov's paper-and-pencil test was used to measure persistence variables. Academic achievement was measured according to the four parameters: Phonetics, Grammar, Speaking and Political vocabulary based on the grades students received during the academic year. The analysis revealed that persistence displays different associations with academic achievement variables in more and less successful students subsamples, the general prominence of this trait is more important for unsuccessful students. Phonetics is the academic achievement variable most associated with persistence due to its nature, a skill one can acquire through hard work and practice which is the definition of persistence. Grammar as an academic achievement variable is not associated with persistence and probably relates to other factors. Unsuccessful students may have difficulties in separating various aspects of language acquisition from each other which should be taken into consideration by the teachers.
\end{abstract}

Key words: persistence, personality traits, academic achievement, foreign language, language acquisition, System-Functional Approach

\section{Introduction}

The concept of studying any subject and especially a foreign language has dramatically changed in the recent years. Several years ago, all the efforts were aimed at acquiring as much knowledge as possible during the years of higher education and applying this knowledge successfully. The acquired knowledge was considered as the final product of the education.

Nowadays the students are expected to become "lifelong" learners (Rogers, 2003; Gordeeva, 2011). "Lifelong learning and continuing professional development are arguably essential for graduates and other workers to remain competent. Therefore, the initiation of key skills development programs and policies in Higher Education has in turn led to an examination of how students reflect on and record their development, and activities which are central to helping them become lifelong learners" (McAvinia, Oliver, 2001, p. 209). Not everybody can grasp this idea and put up with continuous learning, 
perfecting their knowledge step by step through their professional life. That means that the students of higher education institutions should be psychologically prepared while at the higher school and equipped with the skills and certain attitudes for the continuous personal learning and professional updating the acquired knowledge all through their life.

The wealth of the information existing in the modern society induces graduates to perfect the acquired knowledge using self-study techniques. The most persistent students are already predisposed for lifelong education and learning, as during the years spent at the university they worked out a habit of acquiring as much knowledge as possible during their studies (Sternberg, 1997). Some other students have to be encouraged to do it by the teachers who are to equip them with necessary techniques and attitudes to help them realize the dire necessity of perfecting their knowledge of the subject or failing to apply the knowledge acquired at the university. As a few years after the university the knowledge they get there will become inadequate without constant intensive activities directed at perfecting their abilities to work at the subject with more persistence and perfecting the existing knowledge step by step (Ghanadi, Ketabi, 2014). Lifelong learning is a personal effort of an individual. It depends on the individual's perception of the necessity of doing it and the individual's persistence in doing it, as it is done not according to the curriculum of a university or a higher educational institution, but of the individual's own accord and intention.

"Another aspect of skills development work which can make it hard to reconcile with traditional curricula is the need for skills development to be student-centred. It is difficult to fit this into what is, by necessity, a teacher-centred model, in much the same way that the introduction of student-centred negotiated learning contracts is often felt to be 'practically impossible under the conditions prevailing at universities today'" (Peters, 2001, p. 199). The problem raised by Peters has not lost its topicality, though it has been a subject to thorough research since then. It is the individual personality traits that we must be looking into to develop a truly student-centered curriculum. Naturally, the problem of identification of factors of academic achievement arises (Azhar, Nadeem, Naz, Perveen, Sameen, 2014).

The personality trait of persistence is one of the most important traits for learning and it requires a thorough examination. Most studies reveal, that persistence is a much more prominent factor of academic achievement compared to such factors as curiosity, communication features, motivation, abilities, etc. (Novikova, 2009; Kozhukhova, Krupnov, 2012; Kartashova, 2012; Kartashova, Isaev, 2016; Hergüner, Mirici, 2016).

\section{Methodology}

In our research, we were guided by the eight-component model of the personality trait analysis, developed by A.I. Krupnov (Kozhukhova, Krupnov, 2012; Krupnov, Novikova, Kozhukhova, 2013). According to the system-functional model, the personality trait of persistence is studied as a complete and systematic formation. The eight-component model is further subdivided into two blocks: the motivational-meaningful, including the attitudinal-target, motivational, cognitive and productive components, and the regulatorydynamic, containing in its structure the emotional, dynamic, regulatory, reflectiveevaluative components of the personality trait. 
Each component contains two variables. The attitudinal-target component includes socially significant purposes and personally significant purposes. It takes into account the specific goals, attitudes, intentions and interests of the person.

Motivation of persistence consists of the sociocentricity (incentive connected with the sense of duty, the aspiration to help other people, to deserve respect, etc.) and egocentricity (incentive caused by the aspiration to realize the opportunities and abilities, to be independent, to improve one's welfare, etc.).

The cognitive component is represented by the variables of profound awareness and superficial awareness. It takes into account the depth of the person's understanding of the nature of persistence as a personality trait.

The productive component includes the variables of objectness (the results achieved by the person with the help of persistence in academic performance, work, relations with other people) and subjectness (the results of solving one's personal and financial problems, self-education).

The emotional component includes sthenic emotions (domination of the positive emotions of pleasure, pride, optimism, an anticipation of a positive outcome, etc.) and asthenic emotions (domination of anxiety, pessimism, fear, apathy, etc.) connected with the manifestation of persistence.

The dynamic component is characterized by energy (ergicity) and inactivity (aergicity). It reflects the variety of methods and ways of the realization of persistence: the force, stability and constancy of the aspirations or inertia, inactivity, a weak manifestation of persistence respectively.

The regulatory component is subdivided into internal regulation (internality) and external regulation (externality). It reflects the internal or external locus of control of the person and their self-regulation of persistent behavior.

The reflective-evaluative component contains the variables of operational difficulties (lack of intellectual, communicative or conative habits and skills, etc.) and personal difficulties (a low self-esteem, anxiety, lack of self-confidence, etc.).

Sample. The sample of the research consisted of 115 students of the Faculty of Physics, Mathematics and Natural Science at the RUDN University. The age of the respondents ranged between 16 and 18 years. All of them were mastering a foreign language (English, French, German, Spanish) within the framework of the training program that envisaged a full year of additional studying of various aspects of the foreign languages to prepare the students for obtaining an additional qualification as interpreters and translators in their major subject.

We have selected this specific sample because one of the key points of the study was to isolate, to the best of our ability and resources, the role of persistence as an academic achievement factor. We believe that natural sciences students do not display a prominent interest in language acquisition compared to Linguistic or social sciences or arts and humanities students, which makes them a more "neutral" sample and lets us study persistence "untainted" by another trait, for example, prominent curiosity.

Methods and techniques. In the current research we measured the components of persistence with the help of A.I. Krupnov's paper-and-pencil test developed on the basis of the system-functional model of the personality traits analysis (Kozhukhova, 2011). 
We measured the students' performance according to the four parameters: Phonetics, Grammar, Speaking and Political vocabulary. To provide the data we asked their teachers to assess the students' fluency in the studied foreign language according to these parameters. In addition to the more obvious parameters of Phonetics, Grammar and Speaking we also included the parameter of Political vocabulary as it is important in developing speech competence in many spheres, helps the students master the grammar patterns, it provides the students with the opportunity to develop the skills in translating both from and into a foreign language. We must not forget that political vocabulary is partly international in most European languages, and so it is easy to grasp and is effective in making students fluent in a foreign language. It also dramatically upgrades the vocabulary the students use to a more sophisticated level and prepares them for the scientific language they are going to use in their further research. Studying it the students quickly become more confident in using a foreign language. Apart from the above mentioned more subjective parameters we also took into account their general academic performance (GPA).

\section{Results}

At the first stage of the study, we divided the original sample into 5 subsamples of 23 subjects each according to their academic achievement: the successful students, the aboveaverage students, the average students, the below-average students, the unsuccessful students. The mean value of each academic achievement variable in the original sample was used as the main criterion for division (See Table 1). Standard deviation was not used as this method resulted in unequal subsamples. We focused our research on the two "extreme" subsamples, the successful and the unsuccessful students.

Table 1

Descriptive statistics (academic achievement variables mean values)

\begin{tabular}{|l|c|c|c|c|c|}
\hline \multicolumn{1}{|c|}{ Subsamples } & Phonetics & Grammar & Speaking & $\begin{array}{c}\text { Political } \\
\text { vocabulary }\end{array}$ & GPA \\
\hline Successful students & 4,70 & 4,48 & 4,87 & 4,78 & 4,71 \\
\hline Above-average students & 4,59 & 4,22 & 4,57 & 4,52 & 4,46 \\
\hline Average students & 4,27 & 3,91 & 4,20 & 4,09 & 4,11 \\
\hline Below-average students & 4,07 & 3,71 & 4,04 & 3,92 & 3,91 \\
\hline Unsuccessful students & 3,78 & 3,43 & 3,61 & 3,52 & 3,59 \\
\hline Full sample & 4,28 & 3,95 & 4,26 & 4,17 & 4,16 \\
\hline Mean delta & 0,23 & 0,26 & 0,32 & 0,32 & 0,28 \\
\hline
\end{tabular}

In order to further justify the successful and the unsuccessful students subsamples, we compared the academic achievement variables values in these subsamples using Student's t-test (See Table 2).

Table 2

T-test results for the subsamples (academic achievement variables)

\begin{tabular}{|l|c|c|c|c|}
\hline \multicolumn{1}{|c|}{ Persistence variables } & Successful students & Unsuccessful students & t-test & $p$ \\
\hline Phonetics & 4,70 & 3,78 & 6,930 & 0,000 \\
\hline Grammar & 4,48 & 3,43 & 5,628 & 0,000 \\
\hline Speaking & 4,87 & 3,61 & 6,035 & 0,000 \\
\hline Political vocabulary & 4,78 & 3,52 & 5,832 & 0,000 \\
\hline GPA & 4,71 & 3,59 & 7,456 & 0,000 \\
\hline
\end{tabular}


As seen in Table 2, all the academic achievement variables values are significantly different from each other. The greatest differences in academic achievement between successful and unsuccessful students are found for such variables as Phonetics and Speaking, followed by the Political Vocabulary. It is worth noting that average Grammar grades are the lowest among the academic achievement variables for both subsamples.

At the second stage of the study, we examined academic achievement variables Spearman intercorrelations in the subsamples (See Table 3).

Table 3

Academic achievement variables Spearman intercorrelations

\begin{tabular}{|l|c|c|c|c|c|c|c|c|}
\hline \multirow{2}{*}{ Academic achievement variables } & \multicolumn{2}{|c|}{ Grammar } & \multicolumn{2}{|c|}{ Speaking } & \multicolumn{2}{c|}{ Political vocabulary } & \multicolumn{2}{c|}{ GPA } \\
\cline { 2 - 9 } & SS & USS & SS & USS & SS & USS & SS & USS \\
\hline Phonetics & 0,00 & $0,40^{\star}$ & $0,59^{\star}$ & $0,78^{\star \star}$ & 0,34 & $0,67^{\star}$ & $0,56^{\star}$ & $0,71^{\star \star}$ \\
\hline Grammar & & & $0,49^{\star}$ & $0,52^{\star}$ & $0,40^{\star}$ & $0,60^{\star}$ & $0,73^{\star \star}$ & $0,84^{\star \star}$ \\
\hline Speaking & & & & & $0,73^{\star \star}$ & $0,72^{\star \star}$ & $0,64^{\star}$ & $0,81^{\star \star}$ \\
\hline Political vocabulary & & & & & & & $0,69^{\star \star}$ & $0,88^{\star \star}$ \\
\hline
\end{tabular}

${ }^{*} p<0,05,{ }^{* *} p<0,01$, two tailed.

SS stands for Successful students, USS stands for unsuccessful students.

Spearman correlation analysis resulted in 8 significant correlations out of 10 possible correlations for the successful students subsample and in 10 significant correlations out of 10 possible correlations for the unsuccessful students subsample.

For successful students, Phonetics is positively associated with Speaking and GPA, but shows no association with either Grammar or Political Vocabulary. The association with Grammar is completely non-existent $(r=0,00)$. However, for the unsuccessful students Phonetics shows a positive association with all the other academic achievement variables; the most prominent associations are found for Speaking and GPA. The correlation between Phonetics and Speaking makes sense, since Phonetics may affect Speaking in a great way and vice versa. Additionally, one should bear in mind that Phonetics is a skill a student has to spend time to develop properly. The process of such development might even impair the speaking as the students pay attention not only to what they say, but also to how they say it. On the other hand, successful students do not display this connection; perhaps for them these aspects are separated, and they can afford paying less attention to actual pronunciation while speaking as this skill is already sufficiently developed.

For successful students, Grammar is positively associated with all the academic achievement variables except Phonetics, the most prominent correlation is found for GPA. For the unsuccessful students, Grammar also displays positive associations with other academic achievement variables, but the connection with Phonetics is also present. Again, we see that for the unsuccessful it is harder to separate pronunciation from other forms of language activity and it should be noted that all the associations are more prominent for the unsuccessful students compared to the successful students.

Speaking is positively associated with all the academic achievement variables for both subsamples. For the successful students sample the most prominent associations were found for Political Vocabulary; for the unsuccessful students - with the GPA.

For the successful students, Political Vocabulary is positively associated with all the academic achievement variables except Phonetics; for the unsuccessful students, as in 
the case of Grammar, Political Vocabulary also displays positive associations with other academic achievement variables, the connection with Phonetics is also present. We believe, that pronunciation, being a skill, takes a lot to master and thus the process of this skill acquisition and proper interiorization might be connected to other forms of language activity as the student is always preoccupied with the way they speak. We believe that this might be an inhibitor factor to other language acquisition aspects development and result in lower grades.

GPA is positively associated with all the academic achievement variables for both subsamples, which we see as an obvious result, however the associations are more prominent for the unsuccessful students compared to the successful students.

At the third stage of the study, we examined the mean values of each of the persistence variables and academic achievement variables for the subsamples and compared them using t-test (See Table 4).

The results show that successful students on average show a higher degree of Objectness and Energy of persistence and lower degree of Inactivity, Asthenic Emotions, Operational and Personal Difficulties. Thus, successful students are basically more persistent and believe that this trait will help them to achieve greater results in various activities compared to the unsuccessful students.

Table 4

Student's t-test results for the subsamples (persistence variables)

\begin{tabular}{|l|c|c|c|c|}
\hline \multicolumn{1}{|c|}{ Persistence variables } & Successful students & Unsuccessful students & t-test & $p$ \\
\hline Socially Significant Purposes & 34,13 & 33,26 & 0,366 & 0,716 \\
\hline Personally Significant Purposes & 36,74 & 36,83 & $-0,034$ & 0,973 \\
\hline Sociocentric Motivation & 30,91 & 29,52 & 0,487 & 0,629 \\
\hline Egocentric Motivation & 35,39 & 34,70 & 0,262 & 0,795 \\
\hline Profound Awareness & 36,91 & 33,48 & 1,527 & 0,134 \\
\hline Superficial Awareness & 15,83 & 15,13 & 0,201 & 0,841 \\
\hline Objectness & 35,87 & 30,78 & 2,087 & $0,043^{\star}$ \\
\hline Subjectness & 34,78 & 34,04 & 0,268 & 0,790 \\
\hline Energy (Ergicity) & 35,78 & 23,17 & 7,739 & $0,000^{\star}$ \\
\hline Inactivity (Aergicity) & 11,00 & 23,70 & $-5,140$ & $0,000^{\star}$ \\
\hline Sthenic Emotions (sthenicity) & 36,04 & 32,78 & 1,642 & 0,108 \\
\hline Asthenic Emotions (asthenicity) & 24,17 & 29,43 & $-2,315$ & $0,025^{\star}$ \\
\hline Internal Regulation (internality) & 32,22 & 31,17 & 0,517 & 0,608 \\
\hline External Regulation (externality) & 14,83 & 16,78 & $-0,758$ & 0,453 \\
\hline Operational Difficulties & 10,83 & 17,87 & $-2,662$ & $0,011^{\star}$ \\
\hline Personal Difficulties & 5,65 & 13,26 & $-2,692$ & $0,010^{\star}$ \\
\hline
\end{tabular}

At the fourth stage of the study, we examined Spearman Correlations between persistence variables and academic achievement variables in the subsamples.

Spearman correlation analysis of the successful students subsample resulted in 4 significant correlations out of 80 possible correlations (See Table 5).

As seen in Table 5, for the successful students subsample the only academic achievement variable to show any significant associations with persistence variables aside from GPA is Phonetics. This variable correlates negatively with Personally Significant Purposes, Profound Awareness, and Asthenic Emotions, i.e. successful students who are less 
concerned with personal goals and are less likely to feel negative emotions in persistence realization, tend to score higher in Phonetics. It is interesting that the less profound understanding of persistence is also associated with higher grades in Phonetics.

Table 5

Spearman Correlations between persistence variables and academic achievement variables (successful students)

\begin{tabular}{|l|c|c|c|c|c|}
\hline \multicolumn{1}{|c|}{ Persistence variables } & Phonetics & Grammar & Speaking & Politics vocabulary & GPA \\
\hline Socially Significant Purposes & $-0,29$ & $-0,22$ & $-0,07$ & 0,00 & $-0,32$ \\
\hline Personally Significant Purposes & $-0,42^{\star}$ & $-0,17$ & $-0,19$ & $-0,08$ & $-0,37$ \\
\hline Sociocentric Motivation & $-0,21$ & 0,24 & $-0,16$ & $-0,08$ & 0,12 \\
\hline Egocentric Motivation & $-0,16$ & $-0,03$ & $-0,28$ & $-0,39$ & $-0,16$ \\
\hline Profound Awareness & $-0,42^{\star}$ & $-0,04$ & $-0,30$ & $-0,35$ & $-0,31$ \\
\hline Superficial Awareness & $-0,31$ & 0,22 & $-0,01$ & 0,06 & 0,01 \\
\hline Objectness & $-0,19$ & 0,07 & $-0,02$ & $-0,06$ & $-0,05$ \\
\hline Subjectness & $-0,16$ & $-0,38$ & $-0,21$ & $-0,33$ & $-0,45^{\star}$ \\
\hline Energy (Ergicity) & 0,32 & $-0,06$ & 0,32 & 0,18 & 0,12 \\
\hline Inactivity (Aergicity) & $-0,39$ & 0,01 & $-0,13$ & $-0,08$ & $-0,24$ \\
\hline Sthenic Emotions (sthenicity) & $-0,14$ & $-0,12$ & $-0,10$ & $-0,10$ & $-0,17$ \\
\hline Asthenic Emotions (asthenicity) & $-0,41^{*}$ & 0,11 & $-0,01$ & $-0,23$ & $-0,31$ \\
\hline Internal Regulation (internality) & $-0,24$ & $-0,05$ & $-0,24$ & $-0,13$ & $-0,10$ \\
\hline External Regulation (externality) & $-0,08$ & 0,27 & 0,09 & 0,14 & 0,20 \\
\hline Operational Difficulties & 0,05 & 0,03 & 0,06 & 0,08 & 0,03 \\
\hline Personal Difficulties & 0,01 & $-0,15$ & $-0,12$ & 0,13 & 0,03 \\
\hline
\end{tabular}

${ }^{*} p<0,05,{ }^{\star \star} p<0,01$, two tailed.

GPA shows a negative correlation with Subjectness of persistence, i.e. successful students who tend to think less of their persistence in terms of achieving personal growth display higher grades on average.

Other academic achievement variables do not show any associations with persistence variables.

Spearman correlation analysis of the unsuccessful students subsample resulted in 6 significant correlations out of 80 possible correlations (See Table 6).

As seen in Table 6, for the unsuccessful students subsample the only academic achievement variable that does not show any significant associations with persistence variables is Grammar.

Phonetics correlates negatively with Profound Awareness, Objectness, and Inactivity, i.e. unsuccessful students who do not understand persistence well and do not see it as a trait important for their goals in various activities, tend to score higher in Phonetics. A more prominent persistence is also associated with higher grades in Phonetics.

Speaking is negatively associated with Inactivity, i.e. students with more prominent persistence tend to score higher in Speaking.

Political vocabulary correlates positively with the Energy of persistence, thus more persistent students tend to display better results.

GPA is negatively associated with Inactivity, i.e. unsuccessful students with more prominent persistence tend to display greater academic achievement. 
Spearman Correlations between persistence variables and academic achievement variables (unsuccessful students)

\begin{tabular}{|l|c|c|c|c|c|}
\hline \multicolumn{1}{|c|}{ Persistence variables } & Phonetics & Grammar & Speaking & Politics vocabulary & GPA \\
\hline Socially Significant Purposes & $-0,10$ & $-0,16$ & 0,11 & 0,16 & 0,00 \\
\hline Personally Significant Purposes & 0,14 & $-0,01$ & 0,08 & $-0,02$ & 0,07 \\
\hline Sociocentric Motivation & $-0,29$ & $-0,10$ & $-0,14$ & 0,00 & $-0,08$ \\
\hline Egocentric Motivation & $-0,12$ & 0,06 & $-0,04$ & 0,15 & 0,06 \\
\hline Profound Awareness & $-0,46^{\star}$ & $-0,07$ & $-0,30$ & $-0,19$ & $-0,22$ \\
\hline Superficial Awareness & 0,07 & 0,16 & $-0,09$ & 0,27 & 0,15 \\
\hline Objectness & $-0,50^{\star}$ & $-0,06$ & $-0,34$ & $-0,07$ & $-0,20$ \\
\hline Subjectness & $-0,29$ & 0,03 & $-0,06$ & 0,07 & $-0,07$ \\
\hline Energy (Ergicity) & 0,23 & 0,34 & 0,24 & $0,42^{\star}$ & 0,34 \\
\hline Inactivity (Aergicity) & $-0,53^{\star}$ & $-0,33$ & $-0,42^{\star}$ & $-0,33$ & $-0,45^{\star}$ \\
\hline Sthenic Emotions (sthenicity) & 0,08 & $-0,06$ & 0,09 & 0,24 & 0,02 \\
\hline Asthenic Emotions (asthenicity) & $-0,16$ & $-0,15$ & $-0,19$ & 0,01 & $-0,14$ \\
\hline Internal Regulation (internality) & $-0,04$ & 0,21 & 0,18 & 0,12 & 0,22 \\
\hline External Regulation (externality) & 0,11 & $-0,18$ & $-0,02$ & 0,06 & $-0,07$ \\
\hline Operational Difficulties & $-0,33$ & 0,06 & $-0,29$ & $-0,23$ & $-0,12$ \\
\hline Personal Difficulties & $-0,19$ & $-0,01$ & $-0,28$ & $-0,11$ & $-0,14$ \\
\hline
\end{tabular}

${ }^{\star} p<0,05,{ }^{* \star} p<0,01$, two tailed.

\section{Conclusions}

The purpose of this paper is to consider persistence variables and their associations with the academic achievement in language acquisition in Russian university students. Based on an analysis of the published data we suppose that persistence is closely connected with the peculiarities of the students' academic achievement in language acquisition, but the nature of this connection varies between more and less successful students.

Indeed, we found that persistence variables show different correlations with academic achievement variables in the studied subsamples.

It should be noted that Grammar does not show any relation to persistence variables. We believe that the grammar of the other language may depend less on the actual effort to understand it and more on some other factors such as the cognitive features of the student, the teaching methods, general language acquisition ability, etc. These factors are not the subject of the present study.

For unsuccessful students we have found correlations between such variables of persistence as Energy and Inactivity and Political Vocabulary and Speaking and GPA respectively. These correlations suggest that persistence itself (the degree of its prominence) is indeed important for language acquisition albeit only for unsuccessful student. We believe the reason is that this subsample has to make a greater effort to achieve any result in language acquisition.

For successful students, we have found fewer correlations with persistence variables compared to unsuccessful students. The only academic achievement variables for this subsample to have any associations with persistence are Phonetics and GPA.

Phonetics is one of the most difficult aspects of language to acquire, and it comes as no surprise that it shows up the most in our study. 
In case of the successful students subsample we see that Phonetics correlates negatively with three persistence variables: Personally Significant Purposes, Profound Awareness, and Asthenic Emotions. The first two correlations seem hard to explain, perhaps, students who are less concerned with their own goals tend to work better on their Phonetics skills. We believe those associations require more research on a larger sample. The last Phonetics correlation is, however, more straight and forward: successful students who tend to experience less negative emotion score higher in Phonetics.

Unsuccessful students display a different set of three negative correlations between the persistence variables and Phonetics: Profound Awareness, Objectness, and Inactivity. These correlations are more comprehensive, as students who generally understand their own persistence and its role in their success, and also as show a higher degree of the trait, are expected to score higher in Phonetics due to harder work required to gain this skill.

The noticeable difference between the subsamples lies, in our opinion, in the fact that more successful students do not have to work as hard on the actual skill acquisition, perhaps, they gain the basic skill faster and improve upon it.

This assumption is further supported by the academic achievement variables intercorrelations structure. For Successful students, Phonetics as a skill displays less associations with other academic achievement variables and correlates only with Speaking and GPA (due to obvious reasons). However, for unsuccessful students Phonetics correlates with all other academic achievement variables. It looks like unsuccessful students may have difficulties in separating various aspects of language acquisition from each other which results in more intercorrelations between the academic achievement variables and more correlations with persistence as discussed above.

This should be taken into consideration when working with students in a learning environment. Practical applications of the results of the study may include the following:

- Language groups division;

- Teaching techniques adjustment (for various language skill levels);

- Student performance assessment;

- Personal language acquisition trajectories development;

- Learning curve harmonization.

Previous research in this field (Noftle, Robins, 2007; Kozhukhova, 2011; Vorobyeva, Novikova, Shlyakhta, 2015; Krupnov, Novikova, Vorobyeva, 2016) also suggests, that certain academic disciplines are less associated with persistence, namely disciplines in which the students possess some degree of prior knowledge or skill. For most students in our sample English might be viewed as such a discipline.

Further research should focus more on finetuning the samples in order to define more additional language acquisition success factors. Our study clearly shows that despite some more or less universal trends existing in persistence variables and the academic achievement in language acquisition relation there are more subtle factors that determine the exact nature of this relation.

Summing up the results of the study, it can be concluded that:

1. Persistence displays different associations with academic achievement variables in more and less successful students subsamples, the general prominence of this trait is more important for unsuccessful students. 
2. Phonetics is the academic achievement variable most associated with persistence due to its nature, a skill one can acquire through hard work and practice which is the definition of persistence.

3. Grammar as an academic achievement variable is not associated with persistence and probably relates to other factors.

4. Unsuccessful students may have difficulties in separating various aspects of language acquisition from each other which should be taken into consideration by the teachers.

\section{Limitations}

There are a few limitations to our study that should be taken into account when conducting future research in this area. Firstly, one limitation is the sample size. We believe that the results obtained for our subsamples are valid, but we would like to expand the number of subjects in future research.

Another possible limitation of this study was the way of measuring used to collect the data. We measured academic achievement based on the classic five-point grade scale used in Russia. The use of a 100-point scale might improve the accuracy of the results, though the general outcome trend will remain consistent. We would also like to introduce more academic achievement variables.

We believe gradual expansion of the sample by adding attaching additional data pools obtained by different research teams using a set methodology will provide a more comprehensive result and allow to develop better language learning programs for the students.

\section{REFERENCES}

Azhar, M., Nadeem, S., Naz, F., Perveen, F., \& Sameen, A. (2014). Impact of parental education and socio-economic status on academic achievements of university students. European Journal of Psychological Research. Vol. 1 (1), 1-9.

Ghanadi, Z., Ketabi, S. (2014). The relationship between emotional intelligence and learners' beliefs about language learning: Iranian advanced EFL learners in focus. Theory and Practice in Language Studies, 4(3), 518. doi:10.4304/tpls.4.3.518-523

Gordeeva, T.O. (2011). Optimistic attributional style as a predictor of well-being and performance in different academic settings: A new look at the problem. In I. Brdar (Ed.) The Human Pursuit of Well-Being: A Cultural Approach (pp. 159-174). London, New York: Springer. doi: 10.1007/97894-007-1375-8_14.

Hergüner, S., Mirici İ.H. (2016). The Relationship among Trait Emotional Intelligence, Big Five Personality Traits and the Academic Success of EFL Learners. International Journal of Language Academy, 4/3, 225-243. doi:10.18033/ijla.435

Kartashova, V.N. (2012). Methodological Aspects of the Problem Speech Culture Students of Pedagogical Faculty. Psychology of education in a multicultural space, 17(1), 85-90. (In Russ.)

Kartashova, V.N., Isaev, E.A. (2016). Cultural Development of Students: Axiological Approach. Psychology of education in a multicultural space, 34 (2), 114-119. (In Russ.)

Kozhukhova, Yu.V. (2011). Quantitative and qualitative characteristics of persistence of students with different levels of progress in foreign language learning. Bulletin of Peoples' Friendship University of Russia. Series: Psychology and Pedagogics, (1), 78-82.

Kozhukhova, Yu.V., Krupnov, A.I. (2012). Personality traits and success in foreign language acquisition. Bulletin of Peoples' Friendship University of Russia. Series: Psychology and Pedagogics, (1), 107-111. 
Krupnov, A.I., Novikova, I.A., \& Kozhukhova, Y.V. (2013). System-Functional Model of Personality Traits. Academic Journal of Interdisciplinary Studies, 2(9), 407-413. doi:10.5901/ajis.2013. v2n9p407.

Krupnov, A.I., Novikova, I.A., Vorobyeva, A.A. (2016). On the problem of relation between the SystemFunctional and The Five-Factor models of personality traits. Bulletin of Peoples' Friendship University of Russia. Series: Psychology and Pedagogics, (2), 45-56. (In Russ.)

McAvinia, C., Oliver, M. (2002). "But my subject's different": a web-based approach to supporting disciplinary lifelong learning skills. Computers \& Education, 38(1), 209-220.

Noftle, E.E., Robins, R.W. (2007). Personality predictors of academic outcomes: Big Five correlates of GPA and SAT scores. Journal of Personality and Social Psychology, 93(1), 116. doi: 10.1037/00223514.93.1.116.

Novikova, I.A. (2009). Ratio of individually-typical peculiarities of the person and specificity of educational activity of students. Pedagogicheskoe obrazovanie v Rossii, (4), 100-107. (In Russ.)

Peters, O. (2001). Learning and teaching in distance education: analyses and interpretations from an international perspective. Psychology Press.

Rogers, A. (2003). Integrating lifelong learning perspectives. Hamburg: UNESCO Institute of Education.

Sternberg, R.J. (1997). The concept of intelligence and its role in lifelong learning and success. American psychologist, 52(10), 1030-1037. doi: 10.1037//0003-066x.52.10.1030.

Vorobyeva, A.A., Novikova, I.A., Shlyakhta, D.A. (2015). Typological Features of Persistence and Academic Achievement in Linguistic Students. Acmeology, 3(55), 50-51. (In Russ.)

(C) Krupnov, A.I., Kozhukhova, Yu.V., Vorobyeva, A.A., 2017

\section{Article history:}

Received 12 March 2017

Revised 5 April 2017

Accepted 14 April 2017

\section{For citation:}

Krupnov, A.I., Kozhukhova, Yu.V., Vorobyeva, A.A. (2017). Persistence and Academic Achievement in Foreign Language in Natural Sciences Students. RUDN Journal of Psychology and Pedagogics, 14 (2), 143-154.

\section{Bio Note:}

Alexandr I. Krupnov - Doctor of Psychology, Full Professor, Full Professor of the Chair of Social and Differential Psychology of the Peoples' Friendship University of Russia (RUDN University). E-mail: krupnov_ai@rudn.university

Yulia V. Kozhukhova - Assistant Professor of the Chair of foreign languages of the Faculty of Physics, Mathematics and Natural Science of the Peoples' Friendship University of Russia (RUDN University). E-mail: kozhukhova_yuv@rudn.university

Alexandra A. Vorobyeva - Ph.D. in Psychology, Assistant Professor of the Chair of Social Pedagogics of the Institute of foreign languages of the Peoples' Friendship University of Russia (RUDN University). E-mail: vorobyeva_aa@rudn.university 


\title{
НАСТОЙЧИВОСТЬ И УЧЕБНЫЕ ДОСТИЖЕНИЯ СТУДЕНТОВ ЕСТЕСТВЕННО-НАУЧНЫХ НАПРАВЛЕНИЙ ПРИ ОСВОЕНИИ ИНОСТРАННОГО ЯЗЫКА
}

\author{
А.И. Крупнов, Ю.В. Кожухова, А.А. Воробьева \\ Российский университет дружбы народов \\ ул. Миклухо-Маклая, 6, Москва, Россия, 117198
}

\begin{abstract}
В статье рассматриваются результаты эмпирического исследования связи переменных настойчивости и академических достижений студентов при освоении ими иностранного языка. Выборку исследования составили студенты факультета физико-математических и естественных наук РУДН $(n=115)$, разделенные на 5 подвыборок, две из которых подробно описаны в настоящем исследовании (подвыборки наиболее и наименее успешных учащихся). Настойчивость как черта личности изучается в рамках системно-функционального подхода А.И. Крупнова. Для измерения переменных настойчивости использовался бланковый тест А.И. Крупнова. Академические достижения были измерены в соответствии с четырьмя параметрами: фонетика, грамматика, речь и политическая лексика, основанных на оценках учащихся, полученных в течение учебного года. Анализ показал, что настойчивость демонстрирует различные связи с переменными успеваемости у более и менее успешных в освоении иностранного языка студентов, причем эти связи более выражены у менее успешных студентов. Фонетика как навык, который можно приобрести благодаря упорной работе и практике, наиболее тесно связана с настойчивостью. Грамматика практически не связана с настойчивостью, но, вероятно, связана с другими факторами академических достижений. Менее успешные студенты могут испытывать трудности с отделением различных аспектов освоения языка друг от друга, что должны быть учтено в педагогической работе.
\end{abstract}

Ключевые слова: настойчивость, черты личности, академические достижения, иностранный язык, освоение языка, системно-функциональный подход

\section{История статьи: \\ Поступила в редакцию: 12 марта 2017 г. \\ Принята к печати: 14 апреля 2017 г.}

\section{Для цитирования:}

Крупнов А.И., Кожухова Ю.В., Воробьева А.А. Настойчивость и учебные достижения студентов естественно-научных направлений при освоении иностранного языка // Вестник Российского университета дружбы народов. Серия: Психология и педагогика. 2017. Т. 14. № 2. C. 143-154.

\section{Сведения об авторах:}

Крупнов Александр Иванович - доктор психологических наук, профессор, профессор кафедры социальной и дифференциальной психологии Российского университета дружбы народов. E-mail: krupnov_ai@rudn.university

Кожухова Юлия Владимировна - старший преподаватель кафедры иностранных языков факультета физико-математических и естественных наук Российского университета дружбы народов. E-mail: kozhukhova_yuv@rudn.university

Воробьева Александра Андреевна - кандидат психологических наук, старший преподаватель кафедры социальной педагогики Института иностранных языков Российского университета дружбы народов. E-mail: vorobyeva_aa@rudn.university 